\title{
English Language Teachers' Conceptions of Research
}

\author{
Omid Tabatabaei \\ English Department, Najafabad Branch, Islamic Azad University, Iran \\ Yeganeh Nazem \\ English Department, Najafabad Branch, Islamic Azad University, Iran
}

\begin{abstract}
This article was conducted on 150 EFL teachers investigating the conceptions of research. An understanding of this issue is very important to the development of conditions for encouraging teachers to be research engaged in order not to be subservient and take a much more pioneering role in curriculum development. Questionnaire responses were analyzed to determine the teachers' view of research. The findings of this research present that the teachers' conceptions of research are very close to conventional scientific theories and findings. Teachers also reported lack of time, knowledge, and institutional support as influential factors which restrict their abilities to be research engaged. On the whole, this research points to a number of attitudinal, conceptual, and external obstacles to teachers' research engagement. Understanding these is a necessary part of trying to make teachers' research engagement a more possible and doable activity in ELT.
\end{abstract}

Index Terms — research engagement, evidence-based practice, teacher research

\section{INTRODUCTION}

Teachers are one of the most important contributors to educational system, and their responsibility in schools extends beyond carrying out and delivering the curriculum. They also need to know how to recognize and solve problems that may occur within the classroom when they deliver the curriculum (Davis, 1995). Moreover, a qualified teacher should be aware of, and be able to respond to, the direction of new development in teaching. (Lewis \& Munn, 1997). In other words, in modern world, effective teaching needs that teachers engage in educational research in order to improve the standards of their teaching. At the present time, and especially in the developing countries, teachers are expected to follow educational research findings in order to increase the quality of their teaching, and to solve problems that may come up in their classes (Motimore, 2000; Everton, Galton \& pell, 2000; Brown \& Sharp, 2003)

Through research, teachers should examine their own educational practice systematically and carefully. Furthermore, research is about the nature of the learning process and links between practice and theory (Skerritt, 1996) and tries to improve and produce knowledge (Elliot, 1996). Through research, teachers investigate their own practice in order to make beneficial changes, and systematically analyze their own teaching and their students' performance (Capel, Leask \& Turner, 1997; Bassey, 1999). Engaging in research enables teachers to demonstrate on and evaluate different aspects of their work and perform better as teachers (Kyriasu, 1992). So the quality of teaching and learning can be increased in light of research.

Since the past decades, there are continual changes in ways of teaching and learning English and with the development of new technologies and their effects on learning process, speed of these changes has become tremendously increased. Such changes require not only the development of contemporary curriculum but also competent teachers who will cope well with reform system. Bearing this in mind, the educational ministry needs to embark on human resource development program to upgrade the qualification and skills of teachers in different schools (Borg, 2008). There has always been an awareness of the importance of research as an instrument for evaluating the educational process and for moving out teachers of their subservient position and take a much more revolutionary role in the educational process (Borg, 2009).

Teachers research engagement is not an old phenomenon in English language teaching (ELT) so there are only a limited number of empirical studies related to teachers' understandings of research in contrast to a lot of research which suggested teachers how to do research. (Allwright \& Baily, 1991; Nunnun 1992; freeman, 1998). With this in mind, this study aims to uncover teachers' beliefs about research and identify barriers that prevent them to be engaged in research

\section{LITERATURE REVIEW}

\section{A. What Is Research?}

Research is used as a way of developing and interpreting new and profound information on any particular subject. Research creates a greater knowledge of a subject by means of vigorous investigation and testing of the material. Research has opened the door to the development of many theories and has validated or repudiated many hypotheses. 
Research is the foundation of science. Science is solely based on knowledge and knowledge is based on facts; facts are then based on research. Many scientists were researchers before they became scientist. Research is developed in different stages (Brown, 2009).

The first step in research is to find a topic or basis and to have a goal on how you the information will be gathered. Hypothesizing is a very important part of research; it allows you to predict the expected results before any experimental information is obtained. The next process of research is to experiment with materials that are related to your goals based on the information that you have found. If the research brings any new inventions or innovations, the ideas must be able to be duplicated without error. Research is as being a trial and error method. Research can be a very long process when involving a large spectrum of evidence and variables. However, research on a smaller scale can be rather brief when information is obtained through means of internet or instruction. Research has created new innovations since the beginning of time. Thomas Edison conducted research on Electricity and lighting before he created the light bulb. Every person is a researcher respectively in their daily lives. Upon waking up, a new day is at hand, and without the knowledge of what will happen, we look forward to our daily activities and we learn every day.

Research is deeply involved in our daily lives. Research is conducted in the way that we dress, the career choice that we pursue, and ultimately research starts within ourselves. With the world gradually changing, research allows us to study new information and knowledge that may arise. With the new threat of many new pandemics such as swine flu, rising health care, and other abnormal changes in society, Research to find cures, to find ways to help the economy and world market system, is needed now more than ever. Research will be one of the main trailblazers to solve many of the world's problems through the creation of new innovations and ultimately new opportunities to conduct more research (Brown, 2009).

\section{B. The Teacher as Researcher}

The concept of teacher-as-researcher is included in recent literature on educational reform, which encourages teachers to be collaborators in revising curriculum, improving their work environment, professionalizing teaching, and developing policy. Teacher research has its roots in action research. Teachers are subjective insiders involved in classroom instruction as they go about their daily routines of instructing students, grading papers, taking attendance, evaluating their performance as well as looking at the curriculum. Traditional educational researchers who develop questions and design studies around those questions and conduct research within the schools are considered objective outside observers of classroom interaction. But when teachers become teacher-researchers, the "traditional descriptions of both teachers and researchers change. Teacher-researchers raise questions about what they think and observe about their teaching and their students' learning. They collect student work in order to evaluate performance, but they also see student work as data to analyze in order to examine the teaching and learning that produced it"

Teacher-researchers can be characterized as those practitioners who attempt to better understand their practice, and its impact on their students, by researching the relationship between teaching and learning in their world of work. Ramani (1987) shows how teachers in training can move towards 'theory discovery' from the starting-point of their own observations of the raw data of recorded classes, lesson plans, and so on. Murphy (1985) discusses the necessarily active role of teachers in all stages of the process of course evaluation.

\section{Research Engaged Teachers}

Findings of researches revealed that only a limited number of respondents had understood the nature of research (Borg, 2006). in recent years there have been a number of funded initiatives in UK, USA and some countries around Persian Gulf like Oman took aim at expanding teachers research engagement (e.g. see the DFES website or visit htt://aera.net).

Here are some of previous studies in this area. Warrall (2004) surveyed 26 teachers in UK. Most common cited reason for being research engaged was' to generate a better understanding of specific issues in teaching and learning'.

In this study and in Barker (2005) that interviewed 21 teachers. The results revealed that most respondents found 'lack of external pressure', 'lack of time' and 'lack of institutional supports' as main obstacles which they face with.

There are some researches that focused on organizational responsibility for doing research. (Ebbut, 2001)

\section{Evidence-based Practice}

Evidence-based practice (EBP) is an interdisciplinary approach to clinical practice that was introduced in 1992. First it started in medicine then spread to other areas such as psychology and education. Its fundamental principles are that all decisions made must 1) be based on researches2) that these research studies are chosen and interpreted base on some specific norms usually these norms are based on what counts as evidence (Roberts \& Yeager, 2004).

The method of EBP is the way we go about findings and carrying out interventions that clients deserved to be provided with. (Cournoyer, 2003; Gibbs 2003; and Rubin 2007)

\section{RESEARCH QUESTIONS}

This study was an attempt to understand the conceptions of research held by L2 teachers. The following questions were, then, addressed: 
1. What are the characteristics of research in L2 teachers' point of view?

2. What are L2 teachers' perception of their institutional culture (e.g. lack of support or collaboration from colleagues) in relation to research?

3. To what extent are teachers' conceptions of characteristics of good quality research associated with their experience and highest relevant qualification in ELT?

\section{Methodology}

\section{A. Participant}

This study was conducted with 150 English language teachers. Their qualification and background information (years of experience, relevant qualification to ELT and age of learners they teach...) were identified in section 6 of the questionnaire.

With the aim of obtaining a broad perspective on the issues under study, the researcher approached a number of ELT contexts to invite practicing teachers (the only criteria for teachers participation) teaching at high school, university or language schools. In each context, 50 teachers were invited to take part in this study. The participants were chosen through cluster random sampling. As it was said before, this study comprised three different contexts: universities, high schools, and language schools. In each context cluster random sampling with the following steps was applied.

For the first context including universities, at first the list of all existing universities in Isfahan Province was taken from Wikipedia, all universities involved in Iran Higher Education System. Each university was given a number, without any order like alphabetical ordering, and considered as one cluster. Second, 5 of them were chosen randomly. The chosen universities included Isfahan University, Islamic Azad University of Dehaghan, Higher Education Institute of Shekh-e-Bahaee, Islamic Azad University of Mobarakeh and Kashan University. In third step, all ELT teachers in the chosen universities were sent an invitation to take part in this study.

Teachers of the second context, high schools, were chosen by taking the following steps. The list of all high schools in Isfahan province was taken from Educational and Training organization and without any order a number was assigned to each of them. Then 10 of them were chosen randomly. The chosen high schools were, Maarefat High School in Shahreza, Adab High school in Isfahan, Behesh Ayeen High School in Isfahan, All ELT teachers of the chosen high schools were participants of this study.

As mentioned earlier, the third context was related to language schools. In 1382 the new law was passed in relation to academic activities. Based on this law, most scientific and cultural organizations, including language schools were required to operate under the supervision of Educational and Training Organization. So with the help of that organization it was possible to have the list of the majority of language schools in Isfahan Province. In the second step, 5 of language schools were chosen randomly and all ELT instructors were invited to participate in this study. The chosen language schools included Nahid Cultural and Scientific Institute in Dehaghan, Shokouh Language Academy in Shahreza, Javan Language Center in Isfahan, Pouyesh Language Center in Isfahan, and Pardis Language Center in Najafabad.

\section{B. Instruments}

\section{Questionnaire}

In the form of a questionnaire let large amounts of data be collected efficiently, economically, and in a standardized manner (Aldridge \& Levine, 2001). The questionnaire used in this study included four sections, focusing on the teachers' views about the characteristics of good quality research and their background information in addition to their understanding of research. The goal was to obtain a broad perspective on issues under study and with this goal in mind the researcher approached a number of ELT contexts. To facilitate the achievement of these goals, two modes of administration were used, hard copy and email attachment.

The questionnaire used in this study was the instrument developed by Borg (2009). The questionnaire was piloted with a group of 21 English language teachers and its length, wording, and organization were revised and changed base on their feedback and its validity and reliability have already been established by Borg (2009).

\section{Data Collection Procedure}

Teachers' conception of research, their view about good quality research, their perception of institutional culture in relation to research and their engagement in research were found through cross-sectional survey. The Questionnaire data were collected from a sample of 150 teachers of English. The Researcher's aim was to gain a broad perspective on the issues under study and with this aim in mind the researcher invited practicing teachers (that was the only criterion for teacher 'participation) of English in three different contexts (High schools, language schools and universities) to complete the questionnaire. These contacts played a crucial role in this study by providing access to variety of participants as well as by asking them which mode of administering the questionnaire - hard copy, web-based, or e-mail attachment - would work best in their particular contexts [all three modes of administration were used in the study. The closed questionnaire data were analyzed statistically using SPSS 12 that will be discussed completely in the next chapter.

As mentioned above, the questionnaire contained four sections which aim to answer the research questions. Section 1, included 10 scenarios. The purpose of this section is to elicit teachers' views on the kind of activities which could be 
represented as research. There was no right or wrong answer. Teachers read each scenario and chose one answer to say to what extent they felt each activity described was an example of research.

Section 2 included characteristics of good quality research. There was a list of characteristics that research may have. Teachers should tick one box for each to give their ideas about to what extent it was important in making research a highly qualified one. After this part, second part of this section gave teachers a chance to choose if there were any other characteristics which in their opinion a study must have for it to be called high quality research.

Section 3 was about research culture. Teachers ticked one box for each statement to give their opinion about the general attitude to research in their school in which they were teaching.

Section6, the last section was about general information about the teachers themselves, information like, years of experience, highest relevant qualification to ELT, and type of institution they teach English in most often, the age of the learners they teach most often and etc. Of course, many advantages of questionnaires are affected by some restriction (Dörnyei, 2003), especially when participants are being asked to report their beliefs .Questionnaires, also, often create on the surface answers and do not allow in-depth exploration of particular issues. Because of this limitation, direct questionnaire items of the type 'what are your beliefs/views about research?' or 'what is research?' were avoided; furthermore, the questionnaires were supplemented with qualitative data.

\section{Data Analysis}

The closed questionnaire data were analyzed statistically using SPSS19. The obtained results about teachers' idea about a research and the characteristics of good quality research, research culture, and to what extent teachers read or do research in addition to the effect of research on teaching and reasons of not doing or reading research have been shown in tables of frequency and percentage and also in bar graphs.

\section{RESULTS}

\section{A. Scenarios}

In this section, the teachers were asked to point to what extent they felt the activities descried in ten scenarios were or were not research. The findings for this section are shown after each scenario.

The findings of this section are summarized in figure 5.1 which gives the whole perspective of this section. Figure 5.1 and table 5.1 classify these results into categories for each scenario, not research, definitely not research and probably not research and, Research, probably research and definitely research. This let have an overall understanding of teachers; answers. (Brown \&Rogers, 2002, Cohen, Manion \& Morrison, 2000). A number of commonly mentioned elements- a problem or a question, data, analysis, and interpretation are mostly cited by teachers as characteristics of an activity can be called research. Characteristics of the process, such as systematicity and rigour, are also commonly cited by teachers. Additionally, it has been discussed that to qualify as research, it needs to be made public (e.g. Freeman, 1996; Stenhouse, 1975).

It is clear from figure 5.1 and table 5.1 that the scenarios which were rated as research by most teachers $(98 \%)$ were number 4 and 9 , number 4 in which a university lecturer conducts a large scale survey and analyzes the data statistically and number 9 in which a teacher asked his trainees to write an essay about the ways of motivating teenage learner of English after that decided to write an article and submitted it to a professional journal. scenario 3 and scenario 10 were also highly rated with $91 \%$ and $88 \%$ judging them as research. All 4 scenarios out of 10 were scenarios which no respondent believed that they were not research.

Scenario 8 was the one least recognized as research (88\% placed it in the 'not research' category). By asking the reasons teachers mentioned that having feedback in class is not normally research. Scenario 7 also received a low rating, with $82 \%$ of teachers rating it as 'not research'. Nevertheless, $16 \%$ of respondents still felt it was probably research .The spread of responses was even more pronounced on scenario 1 . While $26 \%$ said it was probably research, $32 \%$ said it was definitely not. There are some factors here which for some teachers were characteristic of research (e.g. perhaps the use of research in ELT, change and reform); however in others' idea these were not research because there were no research questions or hypotheses or because of analyzing data. The findings here particularly reveals the variety in teachers' understandings in term what count as research.

TABLE5.1.

TEACHERS’' ASSESSMENT OF TEN SCENARIOS

\begin{tabular}{|c|c|c|c|c|c|c|c|c|c|c|}
\hline \multirow{2}{*}{ Items } & \multicolumn{10}{|c|}{ SCENARIOS } \\
\hline & 1 & 2 & 3 & 4 & 5 & 6 & 7 & 8 & 9 & 10 \\
\hline not research & 73.4 & 60 & 8 & 2 & 48.7 & 24.7 & 82.7 & 84 & 1.3 & 12 \\
\hline Research & 26.6 & 40 & 92 & 98 & 51.3 & 75.3 & 17.3 & 16 & 98.7 & 88 \\
\hline Total & 100 & 100 & 100 & 100 & 100 & 100 & 100 & 100 & 100 & 100 \\
\hline
\end{tabular}




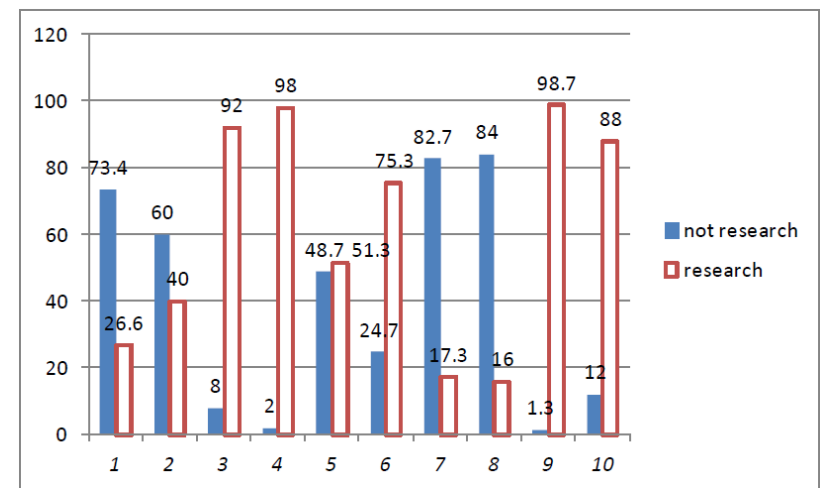

Fig5.1. Teachers' assessment of ten scenarios

\section{B. Characteristics of Good Quality Research}

Section 2 of the questionnaire has focused on the teachers' conceptions of research by asking them to rate the importance to good quality research of a list of characteristics. Table 5.2 and figure 5.2 summarize the responses to this question. For having an efficient table and figure, the four choices in this section reduced to tow answers, less important (unimportant and moderately important) and more important (very impotent and important). Moreover, if participants had not been sure about the characteristics, they could have chosen 'unsure'.

The characteristic which was seen overall to be most important was 'the results give teachers idea they can use' $87 \%$ of rating for this item were in the 'more important' group. 'the results apply to many ELT context' was the second most rated as important, while the third highest rated characteristic was 'information is analyzed statistically'. An overall look declared that usefulness and relativity to ELT in addition to statistically analysis are fundamental concerns. Other points worth noticing here are 'a large number of people are studied' and 'questionnaires are used' rated the least important. Respondents were also unsure for 'experiments are used' and 'the researcher is objective'.

The teachers were asked to suggest more characteristic of good-quality research and 11 respondents made suggestions. Four referred to the need for research reliability and validity as features of highly qualified research. Base on modern discussions the quality of communication is very important factor in research. The need for clear statement of the problem, interesting and useful topics and efficient instrument used to collect data.

TABLE5.2.

CHARACTERISTIC OF GOOD QUALITY RESEARCH

\begin{tabular}{|c|c|c|c|c|c|c|}
\hline \multirow{2}{*}{ item } & \multicolumn{2}{|c|}{ Les important } & \multicolumn{2}{|l|}{ unsure } & \multicolumn{2}{|c|}{ More important } \\
\hline & frequency & percent & frequency & percent & Frequency & percent \\
\hline A. A large number of people are studied & 101 & 67.3 & 49 & 32.7 & 0 & 0 \\
\hline B.A large volume of information is collected & 51 & 34 & 39 & 26 & 60 & 40 \\
\hline C. Experiments are used & 12 & 8 & 111 & 74 & 27 & 18 \\
\hline D. Hypotheses are tested & 47 & 31.3 & 90 & 60 & 13 & 8.7 \\
\hline E. Information is analyzedstatistically & 22 & 14.7 & 55 & 36.7 & 73 & 48.7 \\
\hline F. Questionnaires are used & 120 & 80 & 30 & 20 & 0 & 0 \\
\hline G. The researcher is objective & 0 & 0 & 92 & 61.3 & 58 & 38.7 \\
\hline H. The results are applied to many ELT context & 0 & 0 & 33 & 22 & 117 & 78 \\
\hline I. The results are made public & 39 & 26 & 85 & 56.7 & 26 & 17.3 \\
\hline J. The results give teachers ideas they can used & 2 & 1.3 & 17 & 11.3 & 131 & 87.3 \\
\hline K. Variables are controlled & 9 & 6 & 86 & 57.3 & 55 & 36.7 \\
\hline
\end{tabular}

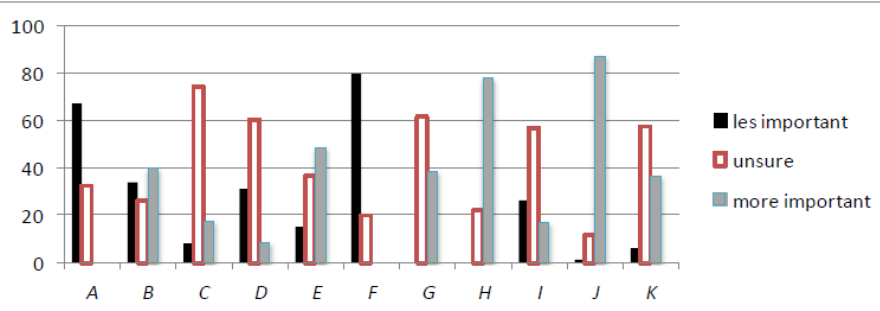

Fig5.2. Characteristic of good quality research

\section{Background Information}

Last section of the questionnaire asked teachers about their years of experience and their highest relevant qualification in ELT. Table5.3 and figure5.3.presents participants' years of experience as an English language teacher. The majority of teachers had 10-14 years experience (42.7\%) and just $1.3 \%$ had more than twenty years experience or only $2 \%$ had less than 4 years experience. 
TABLE5.3.

YEARS OF EXPERIENCE AS AN ENGLISH LANGUAGE TEACHER

\begin{tabular}{|l|l|l|l|}
\hline years & Frequency & Percent & Cumulative Percent \\
\hline $0-4$ & 3 & 2.0 & 2.0 \\
\hline $5-9$ & 36 & 24.0 & 26.0 \\
\hline $10-14$ & 64 & 42.7 & 68.7 \\
\hline $15-19$ & 31 & 20.7 & 89.3 \\
\hline $20-24$ & 14 & 9.3 & 98.7 \\
\hline $25+$ & 2 & 1.3 & 100.0 \\
\hline
\end{tabular}

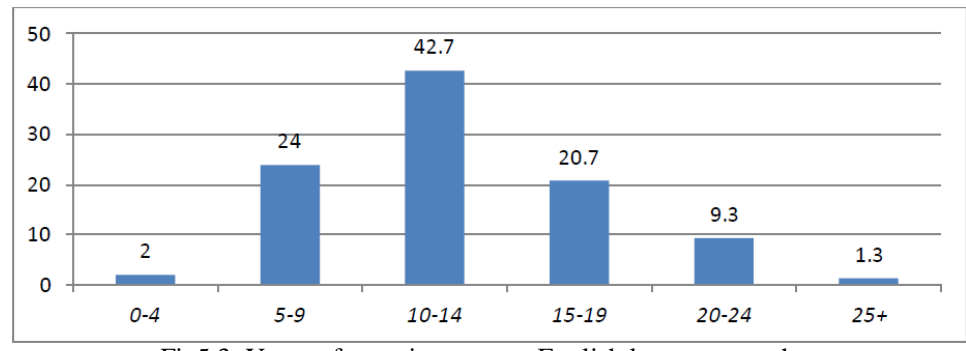

Fig5.3. Years of experience as an English language teacher

Another question of this section, as said before, asked teachers about their highest relevant ELT qualification. Table 5.4 and figure 5.4 summarize their responses. Most of teachers, 51.3\% had bachelor degree and 28\% had masters degree. Among them only $0.7 \%$ had diploma. Having $11.3 \%$ graduated in doctorate, $39.3 \%$ of all participants had post graduate qualification.

TABLE5.4.

HIGHEST RELEVANT QUALIFICATION TO ELT

\begin{tabular}{|c|c|c|c|}
\hline Qualification & Frequency & Percent & Cumulative Percent \\
\hline Certificate & 13 & 8.7 & 8.7 \\
\hline Diploma & 1 & .7 & 9.3 \\
\hline Bachelors & 77 & 51.3 & 60.7 \\
\hline Masters & 42 & 28.0 & 88.7 \\
\hline Doctorate $(\mathrm{PhD})$ & 17 & 11.3 & 100.0 \\
\hline Total & 150 & 100.0 & \\
\hline
\end{tabular}

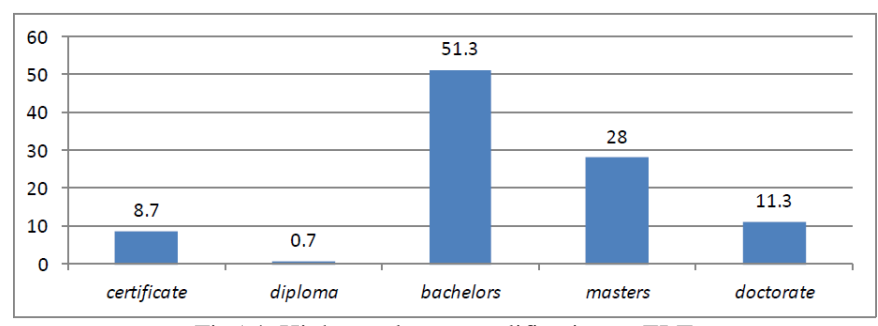

Fig5.4. Highest relevant qualification to ELT

\section{Relationship between Years of Experience as an English Language Teacher \& Characteristic of Good Quality Research}

In the previous part, one variable analysis, the characteristics of a good quality research were analyzed based on three choices and the teachers' experience in ELT based on six choices that both were in ordinal measurement level. So for finding the relationship between them it was needed to use spearman correlation coefficient. The most appropriate way for these two variables is Kendall's tau. This indicator indicates to what extent the reduction or increase in one variable cause reduction or increase in the other. This indicator is flexible between -1 and +1 . 1 indicates the complete relation and 0 indicates no relations. (Saei, 2002)

Cross table 5.5. shows the distribution of variables and the result of analyzing with Kendal's tau. The results show significant relationship (significant level below 0.05) just between 'the results apply to many ELT contexts' and 'experiments are used' as good characteristics of research and years of experience. There were rather weak relations in continuum -1 to +1 between other characteristics and years of experience. 
TABLE5.5.

RELATIONSHIP BETWEEN YEARS OF EXPERIENCE AS AN ENGLISH LANGUAGE TEACHER AND GOOD QUALITY RESEARCH

\begin{tabular}{|c|c|c|c|c|c|c|c|c|c|c|}
\hline \multirow{2}{*}{\begin{tabular}{|l|} 
\\
CHARACTERISTICS \\
OF GOOD QUALITY \\
RESEARCH \\
\end{tabular}} & \multirow[b]{2}{*}{ items } & \multicolumn{6}{|c|}{ Years of experience as an English language teacher } & \multicolumn{3}{|c|}{ Kendall's tauc } \\
\hline & & $0-4$ & $5-9$ & $10-14$ & $15-19$ & $20-24$ & $25+$ & value & Sig. & $\mathrm{N}$ \\
\hline \multirow{3}{*}{ A } & Les important & 1.3 & 14.7 & 31.3 & 14.7 & 5.3 & 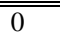 & \multirow{3}{*}{0.014} & \multirow{3}{*}{0.879} & \multirow{3}{*}{150} \\
\hline & unsure & 0.7 & 9.3 & 11.3 & 6 & 4 & 1.3 & & & \\
\hline & More important & 0 & 0 & 0 & 0 & 0 & 0 & & & \\
\hline \multirow{3}{*}{ B } & Les important & 0.7 & 8 & 14.7 & 9.3 & 1.3 & 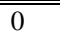 & \multirow{3}{*}{0.007} & \multirow{3}{*}{0.924} & \multirow{3}{*}{150} \\
\hline & unsure & 0 & 6.7 & 10.7 & 4.7 & 4 & 0 & & & \\
\hline & More important & 1.3 & 9.3 & 17.3 & 6.7 & 4 & 1.3 & & & \\
\hline \multirow{3}{*}{$\mathrm{C}$} & Les important & 0 & 0.7 & 4.7 & 2.7 & 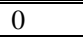 & 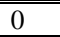 & \multirow{3}{*}{-0.144} & \multirow{3}{*}{0.003} & \multirow{3}{*}{150} \\
\hline & unsure & 2 & 16 & 29.3 & 16 & 9.3 & 1.3 & & & \\
\hline & More important & 0 & 7.3 & 8.7 & 2 & 0 & 0 & & & \\
\hline \multirow{3}{*}{ D } & Les important & 0 & 8.7 & 14 & 6 & 2 & 0.7 & \multirow{3}{*}{0.06} & \multirow{3}{*}{0.4} & \multirow{3}{*}{150} \\
\hline & unsure & 1.3 & 14 & 26 & 13.3 & 5.3 & 0 & & & \\
\hline & More important & 0.7 & 1.3 & 2.7 & 1.3 & 2 & 0.7 & & & \\
\hline \multirow{3}{*}{$\mathrm{E}$} & Les important & "0 & "4 & 8 & 2 & \begin{tabular}{c|c|}
0.7 \\
\end{tabular} & "0 & \multirow{3}{*}{0.115} & \multirow{3}{*}{0.092} & \multirow{3}{*}{150} \\
\hline & unsure & 0.7 & 9.3 & 17.3 & 6.7 & 2 & 0.7 & & & \\
\hline & More important & 1.3 & 10.7 & 1.3 & 12 & 6.7 & 0.7 & & & \\
\hline \multirow{3}{*}{$\mathrm{F}$} & Les important & 2 & 21.3 & 30.7 & 18.7 & 6.7 & 0.7 & \multirow{3}{*}{0.064} & & \\
\hline & unsure & 0 & 2.7 & 12 & 2 & 2.7 & 0.7 & & 0.333 & 150 \\
\hline & More important & 0 & 0 & 0 & 0 & 0 & 0 & & & \\
\hline & Les important & 0 & 0 & 0 & 0 & 0 & 0 & & & \\
\hline G & unsure & 2 & 16 & 22.7 & 13.3 & 6 & 1.3 & 0.014 & 0.865 & 150 \\
\hline & More important & 0 & 8 & 20 & 7.3 & 3.3 & 0 & & & \\
\hline & Les important & $\begin{array}{l}0 \\
\end{array}$ & 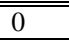 & 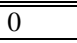 & 0 & 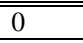 & 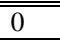 & & & \\
\hline $\mathrm{H}$ & unsure & 0.7 & 10 & 8 & 2.7 & 0.7 & 0 & 0.246 & 0.001 & 150 \\
\hline & More important & 1.3 & 14 & 34.7 & 18 & 8.7 & 1.3 & & & \\
\hline & Les important & 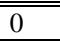 & .7 & 14 & 3.3 & 2 & 0 & & & \\
\hline I & unsure & 2 & 14.7 & 21.3 & 12 & 6 & 0.7 & 0.102 & 0.102 & 150 \\
\hline & More important & 0 & 2.7 & 7.3 & 5.3 & 1.3 & 0.7 & & & \\
\hline & Les important & 0 & 0 & 0.7 & 0 & 0.7 & 0 & & & \\
\hline $\mathrm{J}$ & unsure & 0 & 2 & 5.3 & 3.3 & 0.7 & 0 & -0.042 & 0.315 & 150 \\
\hline & More important & 2 & 22 & 36.7 & 17.3 & 8 & 1.3 & & & \\
\hline & Les important & 0.7 & 2.7 & 2 & 0.7 & 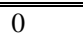 & 0 & & & \\
\hline $\mathrm{K}$ & unsure & 1.3 & 12 & 25 & 11.3 & 6 & 1.3 & 0.055 & 0.422 & 150 \\
\hline & More important & 0 & 9.3 & 15.3 & 8.7 & 3.3 & 0 & & & \\
\hline
\end{tabular}

\section{E. The Relationship between Highest Relevant Qualifications in ELT \& Characteristics of Good Quality Research}

To continue the previous part, for finding the relation between the highest ELT qualification and characteristic of good quality research which both were ordinal variable, Kendall correlation were used and the results are summarized in table 5.6.

As table 5.6 shows, there is negative significant relation (significant level is below 0.05) between relevant qualification in ELT and 'a large volume of information is collected', 'hypotheses are tested', 'experiments are used' and' information is analyze statistically' as characteristics of good research. But there is significant positive relation between ELT qualification and 'variables are controlled' and 'the researcher is objective' as characteristic of good quality research. 
TABLE5.6.

THE RELATIONSHIP BETWEEN HIGHEST RELEVANT QUALIFICATIONS TO ELT \& CHARACTERISTICS OF GOOD QUALITY RESEARCH

\begin{tabular}{|c|c|c|c|c|c|c|c|c|c|}
\hline \multirow[b]{2}{*}{$\begin{array}{l}\text { CHARACTERISTICS } \\
\text { OF GOOD QUALITY } \\
\text { RESEARCH }\end{array}$} & \multirow[b]{2}{*}{ items } & \multicolumn{5}{|c|}{ highest relevant qualification to ELT } & \multicolumn{3}{|c|}{ kendall's tauc } \\
\hline & & certificate & diploma & bachelors & masters & doctorate & value & Sig. & $\mathrm{N}$ \\
\hline \multirow{3}{*}{ A } & Les important & 7.3 & 0.7 & 32.7 & 20 & 6.7 & \multirow{3}{*}{0.051} & \multirow{3}{*}{0.523} & \multirow{3}{*}{150} \\
\hline & unsure & 1.3 & 0 & 18.7 & 8 & 4.7 & & & \\
\hline & More important & 0 & 0 & 0 & 0 & 0 & & & \\
\hline \multirow{3}{*}{ B } & Les important & 0.7 & 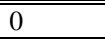 & 15.3 & 11.3 & 6.7 & \multirow{3}{*}{-0.251} & \multirow{3}{*}{0.000} & \multirow{3}{*}{150} \\
\hline & unsure & 1.3 & 0 & 14.7 & 6.7 & 3.3 & & & \\
\hline & More important & 6.7 & 0.7 & 21.3 & 10 & 1.3 & & & \\
\hline \multirow{3}{*}{$\mathrm{C}$} & Les important & (0 & "0 & 1.3 & 4.7 & 2 & \multirow{3}{*}{-0.173} & \multirow{3}{*}{0.008} & \multirow{3}{*}{150} \\
\hline & unsure & 3.3 & 0.7 & 44 & 18 & 8 & & & \\
\hline & More important & 5.3 & 0 & 6 & 5.3 & 1.3 & & & \\
\hline \multirow{3}{*}{$\mathrm{D}$} & Les important & 0.7 & 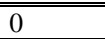 & 15.3 & 10.7 & ב.7 & \multirow{3}{*}{-0.164} & \multirow{3}{*}{0.003} & \multirow{3}{*}{150} \\
\hline & unsure & 7.3 & 0.7 & 28.7 & 16.7 & 6.7 & & & \\
\hline & More important & 0.7 & 0 & 7.3 & 0.7 & 0 & & & \\
\hline \multirow{3}{*}{$\mathrm{E}$} & Les important & 0.7 & 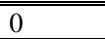 & 6.7 & $\begin{array}{c}5.3 \\
\end{array}$ & 2 & \multirow{3}{*}{-0.28} & \multirow{3}{*}{0.000} & \multirow{3}{*}{150} \\
\hline & unsure & 2 & 0 & 12.7 & 14.7 & 7.3 & & & \\
\hline & More important & 6 & 0.7 & 32 & 8 & 2 & & & \\
\hline \multirow{3}{*}{$\mathrm{F}$} & Les important & 8.7 & 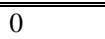 & 40.7 & 22 & 8.7 & \multirow{3}{*}{0.063} & \multirow{3}{*}{0.338} & \\
\hline & unsure & 0 & 0.7 & 10.7 & 6 & 2.7 & & & 150 \\
\hline & More important & 0 & 0 & 0 & 0 & 0 & & & \\
\hline & Les important & 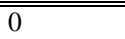 & "0 & 0 & "0 & 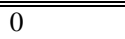 & & & \\
\hline G & unsure & 6.7 & 0.7 & 36.7 & 11.3 & 6 & 0.269 & 0.001 & 150 \\
\hline & More important & 2 & 0 & 14.7 & 16.7 & 5.3 & & & \\
\hline & Les important & 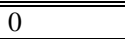 & 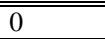 & 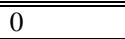 & 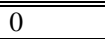 & "0 & & & \\
\hline $\mathrm{H}$ & unsure & 3.3 & 0 & 8 & 8 & 2.7 & -0.035 & 0.655 & 150 \\
\hline & More important & 5.3 & 0.7 & 43.3 & 20 & 8.7 & & & \\
\hline & Les important & 3.3 & "0 & 8.7 & 10.7 & 3.3 & & & \\
\hline I & unsure & 5.3 & 0.7 & 31.3 & 12.7 & 6.7 & -0.06 & 0.363 & 150 \\
\hline & More important & 0 & 0 & 11.3 & 4.7 & 1.3 & & & \\
\hline & Les important & $\begin{array}{l}0 \\
\end{array}$ & 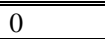 & 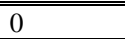 & 0.7 & 0.7 & & & \\
\hline $\mathrm{J}$ & unsure & 0.7 & 0 & 6 & 2.7 & 2 & -0.051 & 0.265 & 150 \\
\hline & More important & 8 & 0.7 & 45.3 & 24.7 & 8.7 & & & \\
\hline & Les important & 0.7 & 0.7 & 2 & 2.7 & 0 & & & \\
\hline $\mathrm{K}$ & unsure & 8 & 0 & 32 & 12 & 5.3 & 0.17 & 0.001 & 150 \\
\hline & More important & 0 & 0 & 17.3 & 13.3 & 6 & & & \\
\hline
\end{tabular}

\section{DISCUSSION}

\section{A. Teachers' Conceptions of Research}

The answers from different groups of 150 teachers of English showed that their understanding of research is very close to conventional scientific theory of research. Key ideas cited by teachers were statistic, objectivity, large sample, variables, publication. Majority of teachers also found usefulness and practicality as very important factors for research. There was high certainty among teachers about the need for result to be generalized or for them to be made public. For teachers making public means publishing in journals. So this factor can be regarded as one barriers teachers faced with to be research engaged.

Another important finding from analysis of responses was the distinction teachers put between research and routine teaching activities. This distinction was cited to explain why some scenarios in section 1 of the questionnaire were not felt to be research. Teaching decision teachers make through process of teaching in their classes like finding appropriate activities or finding students idea about one activity an addition to sharing idea in staff meeting were not count as research in majority of teachers' idea. Cochran-Smith (1999) who investigated about teachers research also achieved to the same distinction between research and teaching activities in teachers ; point on view.

Teachers' understanding of research revealed in this study contribute to understanding reasons why research for a lot of teachers is not important and also is irrelevant and difficult to do. If teachers believe that doing research needs to involve large sample, statistic and formal written publication, it is not an activity possible to do easily. So they hardly ever get engaged in research.

To be aware of teachers' conception of research is the first step in order to encourage them to do and read research. Thus, it is possible to raise awareness among teachers of form of research can be, with emphasis on those approaches to research which are easy to and also such work can be communicated to fellow professionals. Of course this does not mean that the quality should be scarified. Key factors mentioned earlier are essential for research. As Nunan (1997,p. 377) says, "the key distinction should be not whether an activity is practitioner research or regular research but whether it is good research or poor research". 


\section{B. Institutional Research Culture}

As discussed earlier in literature institutional research culture plays a crucial role in teachers' research. In this study teachers' responses indicated that teachers found the institutional culture and their support as very important factors in their engagement in research. Most of them mentioned lack of support from their institution as one of the most important obstacles they deal with.

In terms of specific items related to the institutional culture, over half of teachers agreed that teachers have access to research books and journals and nearly $34 \%$ said teachers have opportunity to learn about current research. The findings here can support the idea of lack of knowledge and time as being the most important barriers for teachers. More than $80 \%$ of teachers said there is no support for them to attend ELT conferences. And pretty large number of teachers believed that research is not built into their educational curriculum.

Although it is easy to ignore lack of time as an excuse, however studies in education showed that productive research engagement is not possible unless institutions provide enough built-in time in addition to support for teachers. Crooks and Arakaki (1999) also interviewed teacher and found that work pressure were also important reason for not being research engaged.

\section{CONCLUSION}

This study shows that some barriers such as attitudinal, conceptual, and procedural also stop teachers to be research engaged. Thus, one issue to understand from the sample in this study is that teachers' understandings of what research is are not in the form which they can feasibly and productively engage in. This reveals the need for awareness-raising work among teachers through which their viewpoints on research can be revised. Furthermore, teachers may not have enough knowledge and practical skills. Considering this problem combined with unsupportive institutions makes clear why for teachers being research engaged is not possible and desirable activities. Having plan to encourage teachers being research engaged is not possible without the organizational, practical and intellectual support which are needed not only to be research engaged but also to improve its quality.

\section{LIMITATIONS OF THE STUDY}

This study would be more generalizable if it was possible to have larger sample, a sample of the whole country. But having this opportunity asks for great deal of time. Even now 280 questionnaires were sent and after a lot of persistence, 150 of them returned. For having second phase of data collection the problem got worse. Teachers were unwilling to take part in written-follow up questions. while I am confident that the findings here reflect the beliefs and practices of the teachers investigated, in research situations there is always the risk that respondents might alter their behaviors.

\section{SUGgestions FOr Further RESEARCH}

Understanding teachers' conception of research and barriers teachers face, remains limited in the field of ELT, so empirical investigation in these issues need to be growing. The investigation highlighted here can also be adapted in other local contexts or the whole country, therefore, providing information can help educational ministry to have motivating research program. The study here focuses on English teachers so it can be very helpful to have teachers' idea in different fields.

Both ministry of education and teachers can take initiatives towards these suggestions and there could be some hopes that the issue of teaching and learning English language in this country someday will have a better sunrise and actually having something to be proud of.

\section{APPENDIX A}

\section{English language teachers' views of research}

What does 'research' mean to you and what role does it play in your life as a professional English language teacher? These are important questions in our field - especially at a time when in many countries teachers are being encouraged to do research as a form of professional development. This International Survey of English Language Teachers asks you for your views on these issues and will take 15-20 minutes to complete. Participation in this study is voluntary. Thank you for your interest in contributing.

\section{SECTION 1: SCENARIOS}

The purpose of this section is to elicit your views on the kinds of activities which can be called research. There are no right or wrong answers. Read each description below and choose one answer to say to what extent you feel the activity described is an example of research.

1. A teacher noticed that an activity she used in class did not work well. She thought about this after the lesson and made some notes in her diary. She tried something different in her next lesson. This time the activity was more successful. 


\begin{tabular}{|c|c|c|c|}
\hline $\begin{array}{c}\text { Definitely not } \\
\text { research } \square\end{array}$ & $\begin{array}{c}\text { Probably not } \\
\text { research } \square\end{array}$ & $\begin{array}{c}\text { Probably } \\
\text { research } \square\end{array}$ & $\begin{array}{c}\text { Definitely } \\
\text { research }\end{array}$ \\
\hline
\end{tabular}

2. A teacher read about a new approach to teaching writing and decided to try it out in his class over a period of two weeks. He video recorded some of his lessons and collected samples of learners' written work. He analyzed this information then presented the results to his colleagues at a staff meeting.

\begin{tabular}{|c|c|c|c|}
\hline $\begin{array}{c}\text { Definitely not } \\
\text { research } \square\end{array}$ & $\begin{array}{c}\text { Probably not } \\
\text { research } \square\end{array}$ & $\begin{array}{c}\text { Probably } \\
\text { research } \square\end{array}$ & $\begin{array}{c}\text { Definitely } \\
\text { research }\end{array}$ \\
\hline
\end{tabular}

3. A teacher was doing an MA course. She read several books and articles about grammar teaching then wrote an essay of 6000 words in which she discussed the main points in those readings.

\begin{tabular}{|c|c|c|c|}
\hline $\begin{array}{c}\text { Definitely not } \\
\text { research } \square\end{array}$ & $\begin{array}{c}\text { Probably not } \\
\text { research } \square\end{array}$ & $\begin{array}{c}\text { Probably } \\
\text { research } \square\end{array}$ & $\begin{array}{c}\text { Definitely } \\
\text { research } \square\end{array}$ \\
\hline
\end{tabular}

4. A university lecturer gave a questionnaire about the use of computers in language teaching to 500 teachers. Statistics were used to analyze the questionnaires. The lecturer wrote an article about the work in an academic journal.

\begin{tabular}{|c|c|c|c|}
\hline $\begin{array}{c}\text { Definitely not } \\
\text { research } \square\end{array}$ & $\begin{array}{c}\text { Probably not } \\
\text { research } \square\end{array}$ & $\begin{array}{c}\text { Probably } \\
\text { research } \square\end{array}$ & $\begin{array}{c}\text { Definitely } \\
\text { research }\end{array}$ \\
\hline
\end{tabular}

5. Two teachers were both interested in discipline. They observed each other's lessons once a week for three months and made notes about how they controlled their classes. They discussed their notes and wrote a short article about what they learned for the newsletter of the national language teachers' association.

\begin{tabular}{|c|c|c|c|}
\hline $\begin{array}{c}\text { Definitely not } \\
\text { research } \square\end{array}$ & $\begin{array}{c}\text { Probably not } \\
\text { research } \square\end{array}$ & $\begin{array}{c}\text { Probably } \\
\text { research } \square\end{array}$ & $\begin{array}{c}\text { Definitely } \\
\text { research }\end{array}$ \\
\hline
\end{tabular}

6. To find out which of two methods for teaching vocabulary was more effective, a teacher first tested two classes. Then for four weeks she taught vocabulary to each class using a different method. After that she tested both groups again and compared the results to the first test. She decided to use the method which worked best in her own teaching.

\begin{tabular}{|c|c|c|c|}
\hline $\begin{array}{c}\text { Definitely not } \\
\text { research } \square\end{array}$ & $\begin{array}{c}\text { Probably not } \\
\text { research } \square\end{array}$ & $\begin{array}{c}\text { Probably } \\
\text { research } \square\end{array}$ & $\begin{array}{c}\text { Definitely } \\
\text { research }\end{array}$ \\
\hline
\end{tabular}

7. A headmaster met every teacher individually and asked them about their working conditions. The head made notes about the teachers' answers. He used his notes to write a report which he submitted to the Ministry of Education.

\begin{tabular}{|c|c|c|c|}
\hline $\begin{array}{c}\text { Definitely not } \\
\text { research } \square\end{array}$ & $\begin{array}{c}\text { Probably not } \\
\text { research } \square\end{array}$ & $\begin{array}{c}\text { Probably } \\
\text { research } \square\end{array}$ & $\begin{array}{c}\text { Definitely } \\
\text { research } \square\end{array}$ \\
\hline
\end{tabular}

8. Mid-way through a course, a teacher gave a class of 30 students a feedback form. The next day, five students handed in their completed forms. The teacher read these and used the information to decide what to do in the second part of the course.

\begin{tabular}{|c|c|c|c|}
\hline $\begin{array}{c}\text { Definitely not } \\
\text { research } \square\end{array}$ & $\begin{array}{c}\text { Probably not } \\
\text { research } \square\end{array}$ & $\begin{array}{c}\text { Probably } \\
\text { research } \square\end{array}$ & $\begin{array}{c}\text { Definitely } \\
\text { research } \square\end{array}$ \\
\hline
\end{tabular}

9. A teacher trainer asked his trainees to write an essay about ways of motivating teenage learners of English. After reading the assignments the trainer decided to write an article on the trainees' ideas about motivation. He submitted his article to a professional journal.

\begin{tabular}{|c|c|c|c|}
\hline $\begin{array}{c}\text { Definitely not } \\
\text { research } \square\end{array}$ & $\begin{array}{c}\text { Probably not } \\
\text { research } \square\end{array}$ & $\begin{array}{c}\text { Probably } \\
\text { research } \square\end{array}$ & $\begin{array}{c}\text { Definitely } \\
\text { research } \square\end{array}$ \\
\hline
\end{tabular}

10. The Head of the English department wanted to know what teachers thought of the new course book. She gave all teachers a questionnaire to complete, studied their responses, then presented the results at a staff meeting.

\begin{tabular}{|c|c|c|c|}
\hline $\begin{array}{c}\text { Definitely not } \\
\text { research } \square\end{array}$ & $\begin{array}{c}\text { Probably not } \\
\text { research } \square\end{array}$ & $\begin{array}{c}\text { Probably } \\
\text { research } \square\end{array}$ & $\begin{array}{c}\text { Definitely } \\
\text { research } \square\end{array}$ \\
\hline
\end{tabular}

\section{SECTION 2: CHARACTERISTICS OF GOOD QUALITY RESEARCH}

1. Here is a list of characteristics that research may have. Tick ONE box for each to give your opinion about how important it is in making a piece of research 'good'. 


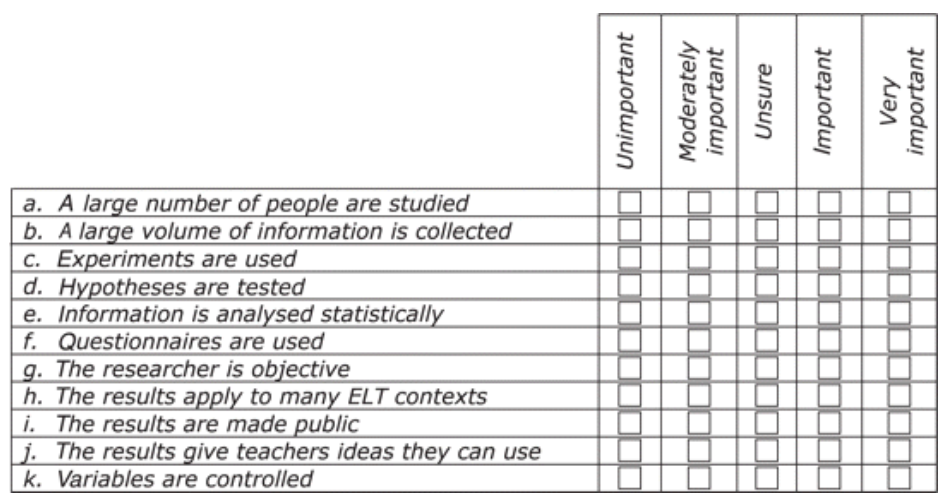

2. If there are any other characteristics which in your opinion a study must have for it to be called 'good' research, please list them here.

SECTION 3: RESEARCH CULTURE

Tick ONE box for each statement below to give your opinion.

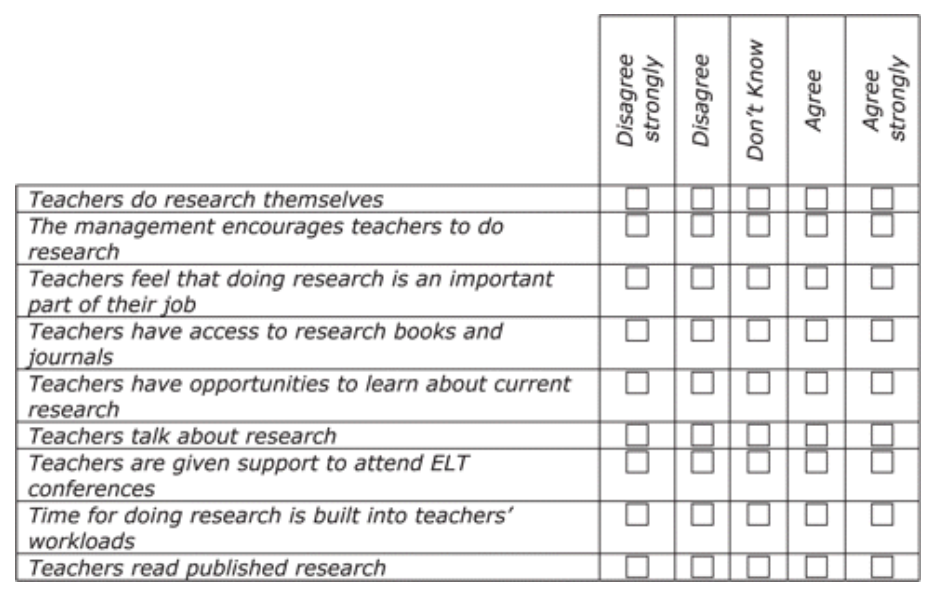

\section{SECTION 4: ABOUT YOURSELF}

1. Country where you work:

2. Years of experience as an English language teacher (Tick ONE)

\begin{tabular}{|l|c|c|c|c|c|}
\hline $0-4 \square$ & $5-9 \square$ & $10-14 \square$ & $15-19 \square$ & $20-24 \square$ & $25+\square$ \\
\hline
\end{tabular}

3. Highest relevant qualification to ELT (Tick ONE)

\begin{tabular}{|l|l|l|l|l|l|}
\hline Certificate $\square$ & Diploma $\square$ & Bachelor's $\square$ & Master's $\square$ & Doctorate $\square$ & Other $\square$ \\
\hline
\end{tabular}

4. Type of institution you teach English in most often (Tick ONE)

\begin{tabular}{|c|c|c|}
\hline Private $\square$ & State $\square$ & Other $\square$ \\
\hline
\end{tabular}

5. Is your language school or centre part of a University? (Tick ONE)

Yes $\square \mathrm{No}$

6. The age of the learners you teach most often (Tick ONE)

\begin{tabular}{|l|l|l|l|}
\hline 12 or younger $\square$ & $13-19 \square$ & $20-25 \square$ & $26+\square$ \\
\hline
\end{tabular}

7. How would you describe your work as an English language teacher? (Tick ONE)

I teach English full-time

I teach English part-time

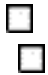

This completes the questionnaire. Thank you for taking the time to respond. 


\section{REFERENCES}

[1] Aldridge, A., \& Levine, K. (2001). Surveying the social world: Principles and practice in survey research. Buckingham: Open University Press.

[2] Barker, P. (2005). Research in schools and colleges. National Educational Research Forum Working Paper 7.2. Retrieved 20 March 2006 from http://www.nerf-uk.org/word/WP7.2ResearchinSchandCol.doc.

[3] Boaz, A. \& Ashby, D. (2003). Fit for purpose? Assessing research quality for evidence based policy and practice. Retrieved 25 September 2004 from http://www.europeanevaluation.org/ docs/boaz.pdf

[4] Borg, S. (2003a). 'Research education' as an objective for teacher learning. In B. Beaven, \& S., Borg (Eds.), The role of research in teacher education (pp. 41-48). Whitstable, Kent: IATEFL.

[5] Borg, S. (2003b). Research in the lives of TESOL professionals. TESOL Matters, 13, 1-5.

[6] Borg, S. (2003c). Teachers' involvement in TESOL research. TESOL Matters, 13, 1-8.

[7] Brown, H. D., \& Rodgers, T. S. (2002). Doing second language research. Oxford: Oxford University Press.

[8] Brown, J. D. (1992). What is research? TESOL Matters 2, 10.

[9] Bryman, A., \& Cramer, D. (2005). Quantitative data analysis with SPSS 12 and 13. Routledge: London.

[10] Burton, J. (1997). Sustaining language teachers as researchers of their own practice. Canadian Modern Language Review, 54, 84-109.

[11] Burton, J. (1998). A cross-case analysis of teacher involvement in TESOL research. TESOL Quarterly, 32, 419-446.

[12] Burton, J., \& Mickan, P. (1993). Teachers' classroom research: Rhetoric and reality. In J. Edge, \& K. Richards (Eds.), Teachers develop teachers research (pp. 113-121). Oxford: Heinemann.

[13] Cohen, L., Manion, L., \& Morrison, K. (2000). Research methods in education (5th ed.). London: Routledge.

[14] Cordingley, P., Bell, M., Evans, D., \& Holdich, K. (2005). Engaging with research and Evidence: What do teachers want and are they getting it? A summary. Paper presented at the International Congress for School Effectiveness and Improvement, Barcelona, 2-5 January 2005

[15] Creswell, J. (2003). Research design: Qualitative, quantitative, and mixed methods approaches (2nd ed.). Thousand Oaks, CA: Sage.

[16] Crookes, G., \& Arakaki, L. (1999). Teaching idea sources and work conditions in an ESL program. TESOL Journal, 8, 15-19.

[17] Davies, P. (1999). What is evidence-based education? British Journal of Educational Studies, 47, 108-121.

[18] Department of Education Training and Youth Affairs. (2000). The impact of educational Research. Canberra, Australia: DETYA

[19] Dornyei, Z. (2002). Questionnaires in second language research: Construction, administration and processing. New York: Lawrence Erlbaum.

[20] Ebbutt, D. (2001). The development of a research culture in secondary schools. Educational Action Research, 10, 123-142.

[21] Freeman, D. (1996). Redefining the relationship between research and what teachers know. In K. M. Bailey, \& D. Nunan (Eds.), Voices from the language classroom (pp. 88-115). New York: Cambridge University Press.

[22] Nunan, D. (1992). Research methods in language learning. Cambridge: Cambridge University Press.

[23] Stenhouse, L. (1975). An introduction to curriculum research and development. London: Heinemann.

Omid Tabatabei is associate professor in TEFL at Islamic Azad University, Najafabad Branch, Iran and currently the Head of the English Department in that university. His areas of interest are testing and assessment, research methodologies, psycholinguistics, language acquisition, and syllabus design. He has published and presented papers in international conferences and journals.

Yeganeh Nazem is studying TEFL at Islamic Azad University, Najafabad Branch, Iran. Her research interests are: Syllabus design and testing and assessment. 